\title{
Development of a Stably Transfected Estrogen Receptor-Mediated Luciferase Reporter Gene Assay in the Human T47D Breast Cancer Cell Line
}

\author{
Juliette Legler, ${ }^{* 1}$ Christina E. van den Brink, $\dagger$ Abraham Brouwer,* Albertinka J. Murk,* Paul T. van der Saag, $\dagger$ \\ A. Dick Vethaak, $\ddagger$ and Bart van der Burg $\dagger$ \\ *Department of Food Technology and Nutritional Sciences, Division of Toxicology, Agricultural University, P.O. Box 8000, 6700 EA Wageningen, \\ The Netherlands; $\dagger$ Hubrecht Laboratory, Netherlands Institute for Developmental Biology, Uppsalalaan 8, 3584 CT Utrecht, The Netherlands: \\ and $\ddagger$ Ministry of Transport, Public Works and Water Management, National Institute for Coastal and Marine Management/RIKZ, \\ P.O. Box 8039, 4330 EA Middelburg, The Netherlands
}

Received July 27, 1998; accepted November 19, 1998

\begin{abstract}
Development of an estrogen receptor-mediated, chemical-activated luciferase reporter gene-expression (ER-CALUX) assay was attempted by stable transfection of luciferase reporter genes in a number of cell lines. Stable transfection of the chimeric Gal4 estrogen receptor and luciferase gene constructs in MCF-7 breast cancer and Hepa.1c1c7 mouse hepatoma cell lines, as well as transfection of a newly constructed luciferase reporter gene pEREtata-Luc in the ECC-1 human endometrial cell line, resulted in constitutive, nonestradiol-inducible clones. Stable transfection of pEREtata-Luc in the T47D breast cancer cell line, however, resulted in an extremely sensitive, highly responsive cell line. Following a 24-h exposure to estradiol (E2), stably transfected T47D.Luc cells demonstrated a detection limit of $0.5 \mathrm{pM}$, an EC50 of $6 \mathrm{pM}$, and a maximum induction of 100 -fold relative to solvent controls. No clear reduction in responsiveness has been found over extended culture periods (50 passages). Anti-estrogens ICI 182,780, TCDD, and tamoxifen inhibited the estradiol-mediated luciferase induction. Genistein, nonylphenol, and o,p'DDT were the most potent (pseudo-)estrogens tested in this system (EC50 100, 260, and $660 \mathrm{nM}$, respectively). Determination of interactive effects of the (pseudo-)estrogens nonylphenol, o,p'DDT, chlordane, endosulfan, dieldrin, and methoxychlor revealed that, in combination with $3 \mathrm{pM} \mathrm{E2}$, (pseudo-)estrogens were additive. Slightly more than additive effects (less than 2 -fold) were found for combinations of dieldrin and endosulfan tested in the range of 3 to $6 \mu \mathrm{M}$. At these concentrations, the combination of endosulfan and chlordane demonstrated additive interaction. The ER-CALUX assay with T47D cells can provide a sensitive, responsive, and rapid in vitro system to detect and measure substances with potential (anti-)estrogenic activity.
\end{abstract}

Key Words: reporter gene assay; in vitro; T47D; luciferase; stable transfectant; anti-estrogens.

An increasing number of reports that chemicals in the environment may mimic the natural hormone estrogen, thereby

\footnotetext{
${ }^{1}$ To whom correspondence should be addressed. Fax: +31 317484931. E-mail: juliette.legler@algemeen.tox.wau.nl.
}

disrupting normal endocrine function, have raised public concern and resulted in a rapidly growing research effort. It has been hypothesized that increased incidence of hormone-sensitive cancers, decreased sperm counts in humans, and compromised gonadal functionality in wildlife may be due to exposure to substances possessing estrogenic activity (reviewed by Colborn et al., 1993). An ever-growing list of environmental, industrial, natural, and pharmaceutical chemicals have been identified as potentially estrogenic. Many of these chemicals, defined as "estrogenic", have structures that deviate considerably from the natural steroid hormone $17 \beta$-estradiol, but can nevertheless evoke effects via the estrogen receptor signal transduction pathway. The effects of estrogens are mediated by binding, with high affinity, to a specific estrogen receptor (ER), a member of the nuclear receptor superfamily (Evans, 1988). In addition to the "classical" ER $\alpha$ form, a second ER form (ER $\beta)$ has recently been identified that has high homology with $\mathrm{ER} \alpha$ but shows a different tissue distribution, ligand binding potential, and trancriptional activity (Kuiper et al., 1997; 1996; 1998; Mosselman et al., 1996; ). Estrogen freely enters the cell and binds to the ER, inducing heat-shock protein 90 dissociation and homodimerization (Fig. 1). The homodimer complex binds to specific DNA sequences called estrogen-response elements (ERE) within regulatory regions of estrogen-responsive genes. Transcription is induced and messenger RNA is translated into protein. The synthesis of these new proteins can alter cellular functions and result in profound effects on physiology (Ing and O'Malley, 1995). In females, estrogen is essential for the development of secondary sex characteristics, the reproductive cycle, fertility, and maintenance of pregnancy. Recently, estrogens have been shown to be essential for male fertility as well (Hess et al., 1997).

A number of in vitro assays have been developed to screen substances for (anti-)estrogenicity (see review by Zacharewski, 1997). These assays include competitive ligand-binding assays (Berthois et al., 1986; Korach et al.; 1978; Migliaccio et al., 


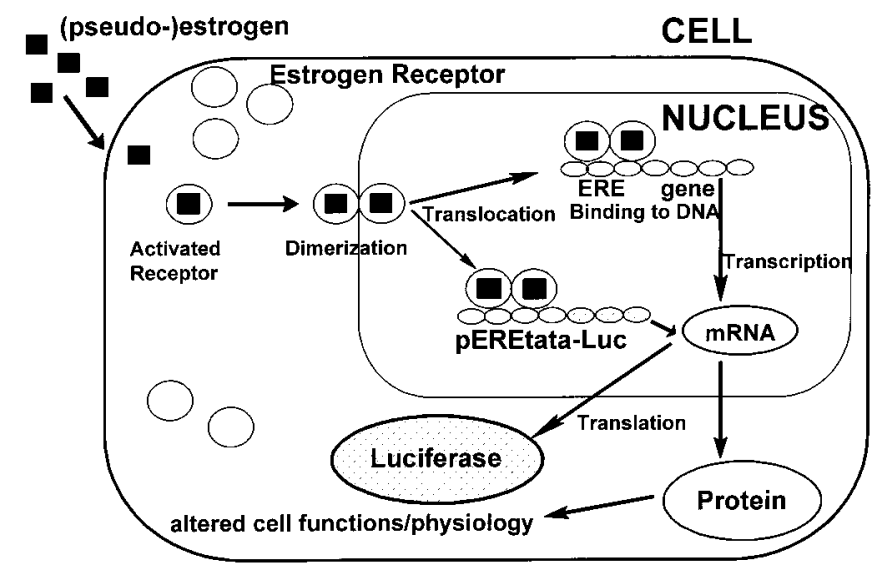

FIG. 1. Mechanism of estrogen action in stably transfected T47D.Luc cells. Pseudo-estrogens enter the cell and bind to and activate the estrogen receptor (ER). Following dimerization, the ER-ligand dimer translocates to the cell nucleus and binds to estrogen response elements (ERE) upstream of genes or present on pEREtata-Luc construct. Transcription and translation of proteins (including luciferase) is induced.

1992), cell proliferation assays (Soto et al., 1995), recombinant receptor/reporter gene assays (Jausons-Loffreda et al., 1994; Pons et al., 1990) and yeast-based screens for estrogens (Connor et al., 1995; Arnold et al., 1996; Routledge and Sumpter, 1997). However, most of these assays suffer from a number of drawbacks that limit their usefulness as a screen for (anti-) estrogenicity. Competitive ligand binding assays for the estrogen receptor are limited because they cannot distinguish between estrogenic and anti-estrogenic substances and do not provide insight into a substance's ability to initiate the molecular cascade of events leading to altered gene expression. Cell proliferation assays are limited by a lack of specificity as mitogens other than estrogens are able to influence the proliferation of human breast cancer cells (van der Burg et al., 1988; Dickson and Lippman, 1995). Yeast-based assays are simple and sensitive, however drawbacks include lack of responsiveness to anti-estrogens (Lyttle et al., 1992; Kohno et al., 1994) as well as possible differences in permeability of compounds through the yeast cell wall, relative to mammalian cell membranes.

In comparison to other existing in vitro assays, we believe recombinant receptor and reporter gene assays based on stably transfected cell lines can provide one of the most specific, responsive, and biologically relevant means to screen substances for potential anti-estrogenic, as well as estrogenic, effects with a high throughput potential. This type of assay is based on the receptor-mediated mechanism of action of estrogens, and reporter gene expression is a culmination of a molecular cascade of events involved in receptor transactivation. To our knowledge, only two estrogen-responsive cell lines stably transfected with recombinant receptor and/or reporter genes have previously been developed. Pons and coworkers developed an MCF-7 cell line stably transfected with the
pVit-tk-Luc construct, which consists of the Xenopus laevis vitellogenin A2 promoter region containing one estrogen-response element upstream of the Herpes simplex virus thymidine kinase promoter that controls expression of the firefly luciferase gene (Pons et al, 1990). A HeLa cell line stably transfected with a Gal4-regulated chimeric estrogen receptor and luciferase reporter gene constructs has also been developed (Jausons-Loffreda et al., 1994). In both stably-transfected cell lines, however, only modest sensitivity and responsiveness to estradiol has been reported.

Recently in our laboratories, stably transfected CALUX (chemical-activated luciferase gene expression) cell-line assays have been developed, as a sensitive and rapid method to determine the potency of individual congeners and mixtures of dioxin-like compounds (Aarts et al., 1995; Garrison et al., 1996; Murk et al., 1996). These cell lines express endogenous aryl hydrocarbon (Ah) receptor and are stably transfected with a dioxin-responsive luciferase reporter gene. In the present study we attempted to develop new, highly responsive stably transfected estrogen receptor-mediated ER-CALUX cell lines for the assessment of (anti-)estrogenic substances. ECC-1 human endometrial carcinoma and T47D human breast adenocarcinoma cells expressing endogenous estrogen receptor were stably transfected with a newly constructed estrogen-responsive luciferase reporter gene, pEREtata-Luc. This construct consists of three estrogen-response elements upstream from a TATA box regulating expression of an enhanced luciferase reporter gene construct. Hepa.1c1c7 mouse hepatoma and MCF-7 human breast adenocarcinoma cells were stably transfected with the chimeric receptor and reporter gene constructs Gal4-HEGO and 17m5-G-Luc. Stable transfection of pEREtata-Luc in T47D cells resulted in a sensitive, highly responsive clone, which was further characterized in doseresponse studies with estradiol as well as some known estrogenic and anti-estrogenic substances.

\section{MATERIALS AND METHODS}

Chemicals. 17 $\beta$-Estradiol (E2, 99\%), methoxychlor (95\%), tamoxifen (99\%), genistein (99\%), al-trans retinoic acid, and ethanol (100\%, pa) were purchased from Sigma Chemical Co. 4-Nonylphenol (92.7\%) was from Fluka. Bisphenol A (99\%) was from Aldrich. Chlordane (97.7\%), endosulfan (99\%), and dieldrin $(98.5 \%)$ were from Riedel-de Haan, The Netherlands. ICI 182, 780 was a kind gift from Dr. A. Wakeling, Zeneca Pharmaceuticals, U.K. o,p'DDT and tetrachlorodibenzo-p-dioxin (TCDD) were kindly provided by the Dutch State Institute for Quality Control of Agricultural Products (RIKILT-DLO). The synthetic progestin Org 2058 was a gift from Organon B. V., Oss, The Netherlands. The synthetic androgen R1881 (methyltrienolone) was purchased from NEN (Boston, MA) and kindly provided by Dr. A. Brinkman, Erasmus University, Rotterdam. For exposure of cells, all chemicals were dissolved in ethanol or dimethyl sulfoxide (DMSO, 99.9\%, spectrophotometric grade, Acros). Antibiotics used for selection of stable clones (puromycin, hygromycin, and G418) were from Duchefa, The Netherlands.

Cell culture. The T47D human breast adenocarcinoma cell line was kindly provided by Dr. R. L. Sutherland (Garvan Institute of Medical Research, Sydney, Australia). The T47D cells were cultured in a 1:1 mixture of Dulbecco's modified Eagle's medium and Ham's F12 medium (DF, Gibco) supple- 
mented with sodium bicarbonate, non-essential amino acids, sodium pyruvate, and $7.5 \%$ fetal calf serum (FCS, Integro, Austria). T47D cells were cultured at $37^{\circ} \mathrm{C}, 7.5 \% \mathrm{CO}_{2}$. The ECC-1 human endometrial carcinoma cell line was a kind gift from Dr. P.G. Stayaswaroop (Pennsylvania State University, State College, PA). ECC-1 cells were cultured in RPMI (Gibco) supplemented with $1 \mathrm{ng} / \mathrm{ml}$ insulin and 5\% FCS (Sigma). The MCF-7 human breast cancer cell line was acquired from the American Type Culture Collection (ATCC, USA). The Hepa 1c1c7 mouse hepatoma cell line was kindly provided by Dr. J. P. Whitlock, Jr. (Stanford University, Palo Alto, CA) The MCF-7 and Hepa cell lines were cultured according to Zacharewski et al. (1995), in phenol red-free Dulbecco's minimal essential medium (DMEM, Gibco) supplemented with $10 \%$ FCS. ECC-1, MCF-7, and Hepa cells were cultured at $37^{\circ} \mathrm{C}, 5 \% \mathrm{CO}_{2}$.

For ER-CALUX assays, T47D, MCF-7 and Hepa cells were maintained in assay medium without phenol red, supplemented with $5 \%$ dextran-coated charcoal treated FCS (DCC-FCS). DCC-FCS was prepared by heat inactivation $\left(30 \mathrm{~min}\right.$ at $\left.56^{\circ} \mathrm{C}\right)$ of FCS, followed by two 45 -min DCC treatments at $45^{\circ} \mathrm{C}$ as described by Horwitz and McGuire, 1978. ECC-1 cells were assayed in RPMI with phenol red supplemented with 5\% DCC-FCS.

Receptor and reporter gene constructs. The reporter gene pEREtata-Luc was constructed using the enhanced luciferase reporter gene pGL3-basic (Promega, U.S.A.). Three tandem repeats of the consensus ERE oligo (GAGCTTAGGTCACTGTGACCT) upstream of the minimal human $\mathrm{E}_{1} \mathrm{~B}$ TATA promoter sequence (GGGTATATAAT) were inserted in the Sma1-Bgl II site of the multiple cloning site of pGL3-basic (Fig. 2).

The Gal4-HEGO chimeric receptor and Gal4-regulated luciferase reporter gene $17 \mathrm{~m} 5$-G-Luc were kindly provided by Prof. P. Chambon, INSERM U184, Strasbourg, France. Gal4-HEGO consists of the ligand binding domain of the ER linked to the DNA binding domain (1-147) of the yeast transcription factor Gal4 (Green et al., 1988). The plasmid 17m5-G-Luc consists of luciferase cDNA regulated by the rabbit $\beta$-globin basal promoter and five tandem consensus Gal4 17-mer response elements (Jausons-Loffreda et al., 1994). For stable transfection, a second $17 \mathrm{~m} 5$ luciferase reporter gene (p17m5-G-neoLuc) was constructed by cloning the Pvu1-EcoRV fragment of pMAMneo-Luc (ClonTech, U.S..) containing the sequence for neomycin (G418) resistance in the Pvu1-EcoRV sites of p17m5-G-Luc.

For selection of stable transfected clones, the following selection plasmids were used: for puromycin selection, pPur (ClonTech, U.S.); for hygromycin selection, pGK-Hyg (Te Riele et al., 1990); and for G418 selection, pSV2-Neo (Hoglund et al., 1992).

Stable transfection: ECC-1, MCF-7 and Hepa.1c1c7 cell lines. Six-16 h prior to transfection, ECC-1, MCF-7, and Hepa.1c1c7 cells were seeded at $50 \%$ confluency in three wells of a 6-well plate in $4 \mathrm{ml}$ culture medium per well. Transfection was carried out according to the calcium phosphate precipitation method (Sambrook et al., 1989). In ECC-1 cells, $4.65 \mathrm{mg}$ pEREtata-Luc and $4.65 \mathrm{mg}$ pPur was transfected per well, using $250 \mu \mathrm{l}$ HEPES-buffered solution (HBS, consisting of $42 \mathrm{mM}$ HEPES, $275 \mathrm{mM} \mathrm{NaCl}, 10 \mathrm{mM} \mathrm{KCl}, 1.4$ $\mathrm{mM} \mathrm{Na}_{2} \mathrm{HPO}_{4}, \mathrm{pH} 7.05$ ) and $250 \mu 1250 \mathrm{mM} \mathrm{CaCl}_{2}$ per well. For MCF-7 and Hepa cells, cells were transfected with either $0.6 \mathrm{mg}$ pGal4HEGO, $3 \mathrm{mg}$ p17m5-G-Luc and $1.5 \mathrm{mg}$ pSV2Neo or $0.6 \mathrm{mg}$ pGal4 HEGO and $3 \mathrm{mg}$ p17m5-G-neo-Luc. After $24 \mathrm{~h}$, the cells were trypsinized and per well distributed over five $100-\mathrm{mm}$ petri dishes. Medium was replaced every three days with culture medium containing $1 \mathrm{mg} / \mathrm{ml}$ puromycin (ECC-1 cells) or 1000 mg/ml G418 (MCF-7 and Hepa cells) until clones formed which were large enough to isolate (about two to three weeks).

Luciferase-positive clones were screened, using a single-photon detecting camera (Argus 50, Hatamatsu) according to the method described by Pons et al., 1990. Briefly, clones in 100-mm dishes were exposed for $24 \mathrm{~h}$ to $10 \mathrm{nM} \mathrm{E2}$. Luciferin $(0.3 \mathrm{mM})$ was added to the culture medium, and dishes were immediately introduced into the dark room of the single-photon counting camera for luminescence measurement. Light intensity was monitored for 5 to $10 \mathrm{~min}$ per dish. The image of the luminescent cells was superimposed on to the light field image of the dishes, enabling identification of positive clones. Positive clones were isolated using cloning rings and further cultured in 24-well plates.
To test for luciferase induction, clones were trypsinized and seeded over 3 wells in a white 96-well viewplate (Packard) in assay medium. Following a 24-h incubation, cells were exposed for $24 \mathrm{~h}$ to control (0.5\% DMSO), $10 \mathrm{nM}$ E2, and $10 \mathrm{nM}$ ICI 182,780. Cells were rinsed twice with $50 \mathrm{ml} 0.5 \times$ phosphate buffered saline (PBS). Low salt (LS) buffer containing $10 \mathrm{mM}$ Tris $\mathrm{pH}$ 7.8, $2 \mathrm{mM}$ DTT, and $2 \mathrm{mM}$ 1,2 diaminocyclohexane- $\mathrm{N}, \mathrm{N}, \mathrm{N}^{\prime}, \mathrm{N}^{\prime}$-tetraacetic acid was added at a volume of $20 \mu \mathrm{l}$ per well. Following a 10-min incubation on ice, 96-well plates were frozen at $-80^{\circ} \mathrm{C}$ for a minimum of $30 \mathrm{~min}$ to lyse cells. The plates were thawed on ice and shaken for $5 \mathrm{~min}$ at room temperature. Luciferase activity was measured in 96-well viewplates in a luminometer (Labsystems Luminoscan RS), with automatic injection of $100 \mu$ l luciferin "flashmix" containing $470 \mu \mathrm{M}$ luciferin, $20 \mathrm{mM}$ tricine, $1.07 \mathrm{mM}$ $\left(\mathrm{MgCO}_{3}\right)_{4} \mathrm{Mg}(\mathrm{OH}) 2.5 \mathrm{H}_{2} 0,2.67 \mathrm{MgSO}_{4}, 0.1 \mathrm{mM}$ EDTA, $5 \mathrm{mM}$ ATP, and 2 mM DTT, pH 7.8 per well.

Stable transfection: pEREtata-Luc in T47D cell line. Two days prior to transfection, T47D cells were plated at a density of 250,000 cells per $5-\mathrm{cm}$ petri dish on $5 \mathrm{ml}$ of culture medium. Per dish, $18 \mathrm{mg}$ pEREtata-Luc and $2 \mathrm{mg}$ pGK-Hyg were transfected using the calcium phosphate precipitation method described above. Cells were incubated with transfection mixture for $8 \mathrm{~h}$, after which the medium was renewed. The following day, the cells were trypsinized and plated over four 5-cm dishes in culture medium supplemented with 100 $\mathrm{mg} / \mathrm{ml}$ hygromycin (selection medium). Clones were allowed to grow for 10 days, during which time the selection medium was renewed every two to three days. Dishes containing 10-15 large colonies were trypsinized for 1-3 min at room temperature. Individual clones were resuspended in $2 \mu 1$ medium and added to 24-well plates containing $2 \mathrm{ml}$ selection medium. Smaller clones were left an extra 2 weeks to grow and were then isolated in the same manner. To test for luciferase induction, confluent 24 wells were trypsinized and one well per clone was seeded in culture medium and incubated for $24 \mathrm{~h}$. Nontransfected T47D cells were used as control. Medium was removed and cells were lysed in $55 \mu$ l triton-lysis buffer containing $1 \%$ triton X-100, $25 \mathrm{mM}$ glycylglycin, $15 \mathrm{mM} \mathrm{MgSO}_{4}, 4$ mM EGTA (pH 7.8), and 1 mM DTT. A 50- $\mu 1$ portion of cell lysate was transferred to a black 96-well plate (Packard) to which $50 \mu$ l luciferine substrate (LucLite reporter gene assay kit, Packard) was added. Luciferase activity was measured in a scintillation counter (Packard Top Count) for $0.1 \mathrm{~min}$ per well.

ER-CALUX assay procedure. T47D cells, stably transfected with pEREtata-Luc from the most responsive clone, were plated in 24-well plates at a density of 50,000 cells in $0.8 \mathrm{ml}$ DF without phenol red $+5 \%$ DCC-FCS (assay medium) per well, or in black 96-well viewplates (Packard) at a density of 5000 cells per well in $0.1 \mathrm{ml}$ of assay medium. Following a 24-h incubation, cells were approximately $50 \%$ confluent. Assay medium was renewed, and the cells were incubated another $24 \mathrm{~h}$. The medium was again renewed, and the cells were dosed in triplicate in 24-well plates by direct addition of the chemical to be tested, dissolved in ethanol or DMSO to the medium above cells. For 96-well plates, the assay medium containing chemicals was first prepared in $0.8 \mathrm{ml}$ assay medium in 48 -well plates, mixed well, and transferred to the microtiter plate at a volume of $0.1 \mathrm{ml}$ per well. In addition to one E2 standard curve in triplicate per experiment, control wells, solvent control wells, and $\mathrm{E} 2$ calibration points $(6 \mathrm{pM}$ and $30 \mathrm{pM})$ were included in triplicate on each plate. The maximum solvent concentration used was $0.2 \%$. Cells were dosed for $24 \mathrm{~h}$ prior to luciferase measurement. For 24-well plates, medium was removed, and the cells were lysed in $100 \mu \mathrm{l}$ triton-lysis buffer. Lysis was carried out by gentle shaking at $4^{\circ} \mathrm{C}$ for a minimum of one h. A 50- $\mu \mathrm{l}$ sample of the cell lysate was then transferred to a black 96-well plate, $50 \mu 1$ luciferin substrate was added and the luciferase activity was assayed in a scintillation counter for $0.1 \mathrm{~min}$ per well. For 96 -well viewplates, $50 \mu \mathrm{l}$ LucLite was added directly to the medium above cells and the plates were shaken gently for 10 min at room temperature to stimulate cell lysis. The transparent bottom of the viewplates was covered by a black sticker prior to luciferase measurement in a scintillation counter (Packard Top Count).

Potential cytotoxicity of pseudo-estrogens was controlled by microscopic visualization of the cells. In addition, a "CytoLite" (Packard) luminescent, non-separation assay kit for the determination of viable cell numbers was used, 
according to manufacturer's specifications, in black 96-well viewplates. T47D.Luc cells were seeded and exposed to pseudo-estrogens in the same manner as outlined in the ER-CALUX assay procedure.

Data and statistical analysis. To determine the EC50 and detection limit of E2 in the ER-CALUX assay, a complete standard curve was included in each assay. The standard curve was fitted (sigmoidal fit, function: $y=a_{0}+a_{1}$ $/\left(1+\exp \left(-\left(x-a_{2}\right) / a_{3}\right)\right)$ using SlideWrite 3.0 for Windows, which determines the fitting coefficients by an iterative process minimizing the $\mathrm{c} 2$ merit function (least squares criterion). The EC50 for E2 and pseudo-estrogens was calculated by determining the concentration at which $50 \%$ of the maximum luciferase activity was reached using the sigmoidal fit equation. The detection limit was calculated as the luciferase activity elicited by the solvent control plus three times the standard deviation.

To determine estradiol equivalents (EEQs), the luciferase response by (combinations of) pseudo-estrogens was interpolated in the linear range of the corresponding E2 standard curve for the same assay. Data shown are representative of a minimum of 2 independent assays. Statistical analysis was performed on luciferase activity by combinations of pseudo-estrogens, as compared to the arithmetic sum of luciferase activity by individual compounds using ANOVA $(\alpha=0.01)$ in SPSS Version 6.0 for Windows. Standard deviation around the arithmetic sum was calculated by taking the square root of the pooled variance of the luciferase activity by the two individual compounds.

\section{RESULTS}

Stable Transfection of Reporter Genes in ECC-1, MCF-7, and Hepa Cell Lines

Following transfection of the pEREtata-Luc reporter gene plasmid in ECC-1 cells and selection with puromycin, 23 luminescent clones were identified using the single photoncounting camera. However, exposure of these clones to $10 \mathrm{nM}$ E2 resulted in no inducible luciferase activity. Luciferase expression in the clones appeared to be constitutive. Similar results were obtained with Hepa.1c1c7 cells transfected with the chimeric receptor and reporter gene constructs pGal4HEGO and p17m5-G-Luc and selected with G418. Fifteen luminescent clones were identified with the photon-counting camera, of which only one demonstrated estradiol-inducible luciferase expression. This clone showed a 5-fold increase in luciferase activity relative to background following 24-h exposure to $10 \mathrm{nM}$ E2. In subsequent assays, however, luciferase activity decreased to three times control levels, suggesting that integration was unstable (data not shown). In Hepa cells transfected with pGal-HEGO and p17m5-G-neo-Luc, all 12 luminescent clones showed constitutive, estradiol-independent luciferase expression. Three separate attempts to stably transfect the chimeric constructs in MCF-7 cells with different concentrations of G418 selection resulted in the formation of unstable clones that ultimately died.

\section{Stable Transfection of pEREtata-Luc in T47D Cells}

A total of 72 T47D clones were isolated and tested for luciferase expression by comparison of activity (without estradiol stimulation) relative to non-transfected cells. Using this method, 28 clones were identified with luciferase expression of

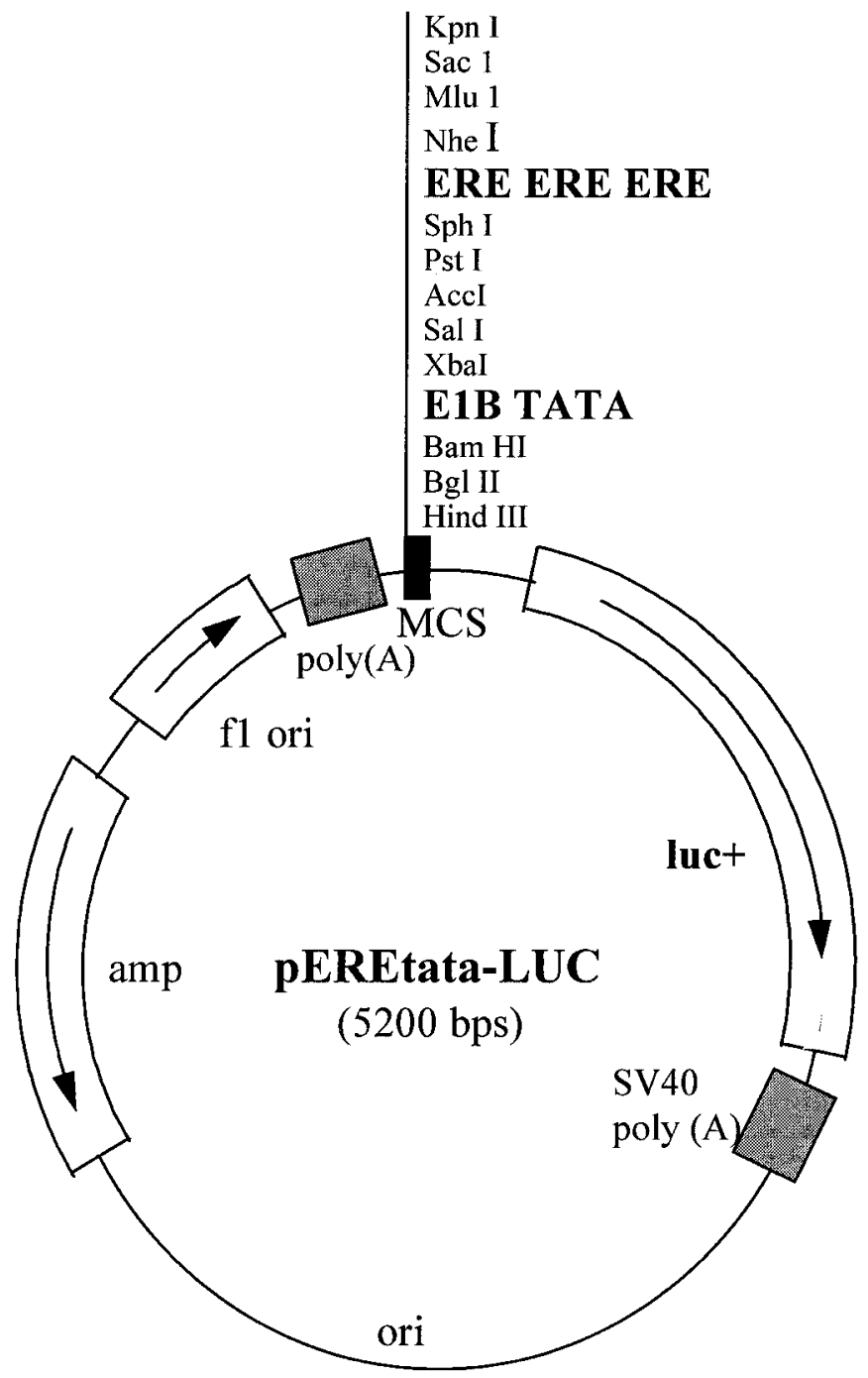

FIG. 2. Schematic representation of the pEREtata-Luc construct. Three estrogen response elements (ERE) upstream of a minimal $\mathrm{E}_{1} \mathrm{~B}$ TATA promoter were inserted in the multiple cloning site (MCS) of the enhanced luciferase (luc+) vector pGL3-basic.

more than 10 -fold induction relative to non-transfected cells. Of these 28 clones, 22 were further characterized, according to the ER-CALUX assay method, in 24-well plates with exposure to $1 \mathrm{nM}$ estradiol. Nine clones were found with greater than 10-fold induction relative to control. Clone ERE.Luc number 42 showed the highest induction and was used for further experiments with the ER-CALUX method.

\section{ER-CALUX Assay with Stably Transfected T47D Cells}

Stable transfection of the pEREtata-Luc construct in T47D cells resulted in a sensitive, highly responsive cell line for the assessment of compounds with (anti-)estrogenic activity. As illustrated in Figure 2, by using the ER-CALUX assay with 


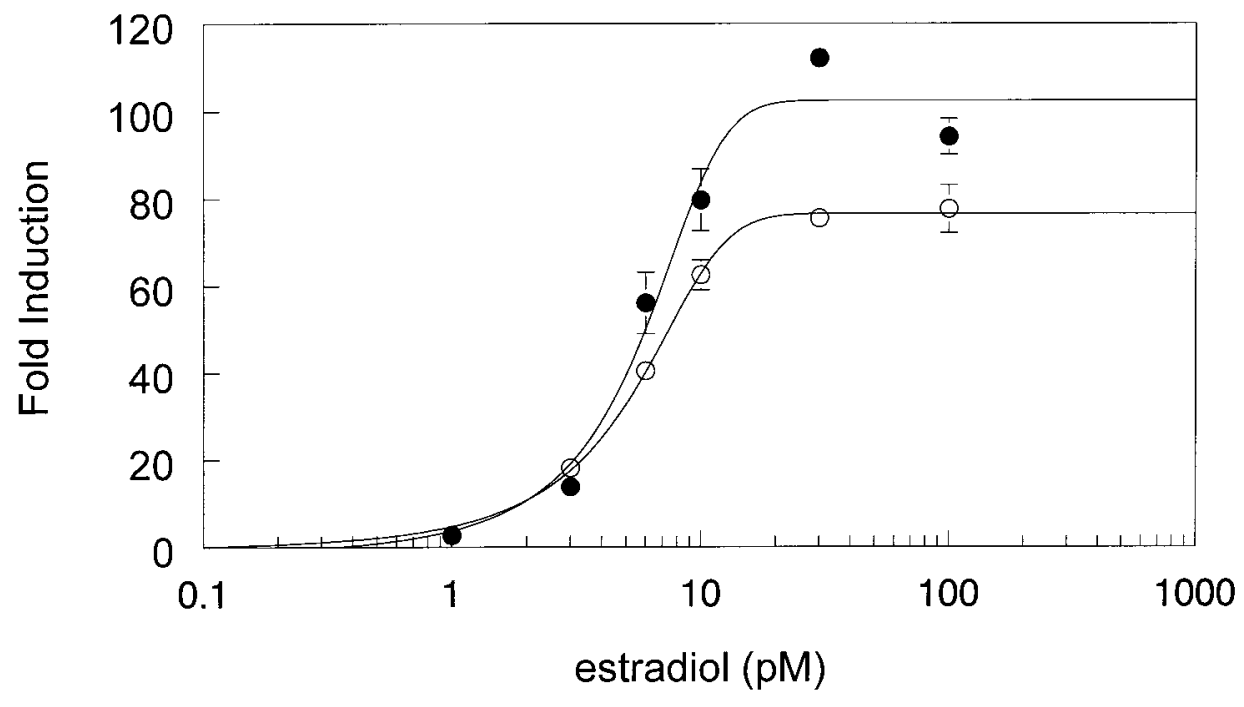

FIG. 3. Luciferase induction relative to solvent control in the ERCALUX assay with T47D cells stably transfected with pEREtata-Luc plated in 24 (solid circles) or 96 (open circles) well plates. Cells were treated with estradiol for $24 \mathrm{~h}(n=3$, avg \pm std).
T47D.Luc cells, substances can be tested for (anti-)estrogenicity based on their specific estrogen receptor-mediated mechanism of action. Upon entering the T47D.Luc cell, substances with estrogenic activity will bind to the endogenous estrogen receptor and activate the receptor. The activated receptor dimer subsequently binds to estrogen-response elements (EREs) upstream of the luciferase gene, leading to recruitment of transcription factors to the promoter and ultimately to luciferase gene expression (Fig. 1).

Response to estradiol. The sensitivity and responsiveness of the ER-CALUX assay with the stably transfected T47D ERE.Luc 42 clone (T47D.Luc cells) was assessed by measuring the luciferase activity induced by E2 compared to solvent control, over a period of 9 months, in cells ranging from passages 9 to 48. Exposure of T47D.Luc cells to estradiol for $24 \mathrm{~h}$ resulted in dose-response related luciferase induction as measured in both 24-well plates and 96-well plates (Fig. 3). In 24-well plates averaged over 15 assays, 102 ( \pm 76 )-fold maximum induction relative to control was reached at $30 \mathrm{pM} \mathrm{E2}$. A detection limit of $0.5( \pm 0.1)$ pM and an EC50 of $5.5( \pm 1.8)$ pM was calculated. Using 96-well plates, a similar EC50 and detection limit were measured in 6 experiments, though maximum induction at $30 \mathrm{pM}$ E2 relative to control was less than in 24-well plates (average 76 ( \pm 31 )-fold). No clear reduction in luciferase activity over prolonged periods of cell culture was found, demonstrating stable integration of the luciferase gene.

Response to other steroids and retinoic acid. Because the T47D cell line expresses other hormone receptors, such as progesterone, androgen and retinoic acid receptors, we determined the potential effects of other endogenous ligands on the estrogen receptor-mediated luciferase response. Luciferase activity in T47D.Luc cells was determined following 24-h treatment with a synthetic progestin (Org 2058), synthetic androgen (R1881), and retinoic acid. No luciferase activity was found by these ligands when tested in concentrations ranging from $1 \mathrm{pM}$ to $10 \mathrm{nM}$ (data not shown).

Response to anti-estrogens. Exposure of T47D.Luc cells to the pure anti-estrogen ICI 182,780 and the Ah receptor agonist TCDD at concentrations ranging from 0.01 to 1000 $\mathrm{nM}$ resulted in luciferase activity equal to or slightly less than control values (Fig. 4). When tested in combination with the EC50 value (6 pM E2), ICI 182,780 completely inhibited luciferase activity at concentrations at or above 1 nM. TCDD was a potent antagonist when co-administered with 6 pM E2, as a concentration as low as 10 pM inhibited luciferase activity by $50 \%$ (Fig. 4). Exposure of cells to tamoxifen alone at lower concentrations $(<100 \mathrm{nM})$ resulted in no luciferase activity, though tamoxifen was

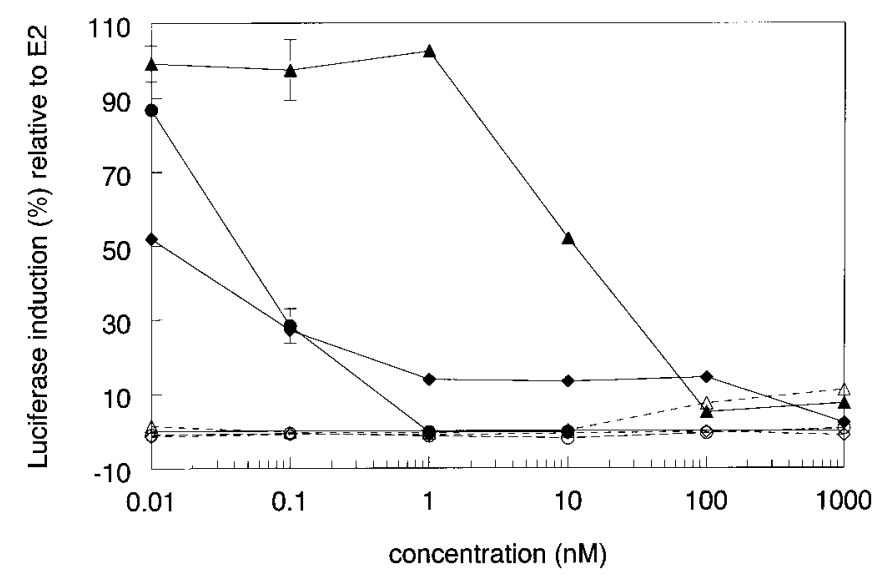

FIG. 4. Luciferase activity (\%) of anti-estrogens relative to estradiol (E2, $6 \mathrm{pM})$ in the ER-CALUX assay. T47D.Luc cells were treated for $24 \mathrm{~h}$ with tamoxifen (triangles), ICI 182,780 (circles) and TCDD (diamonds). Antiestrogens were tested with (solid lines) or without (dashed lines) co-administration of 6 pM E2 $(n=3$, avg \pm std). 
TABLE 1

Potency of Pseudo-Estrogens Relative to Estradiol, Following 24-h Treatment in the ER-CALUX Assay with T47D Luc Cells

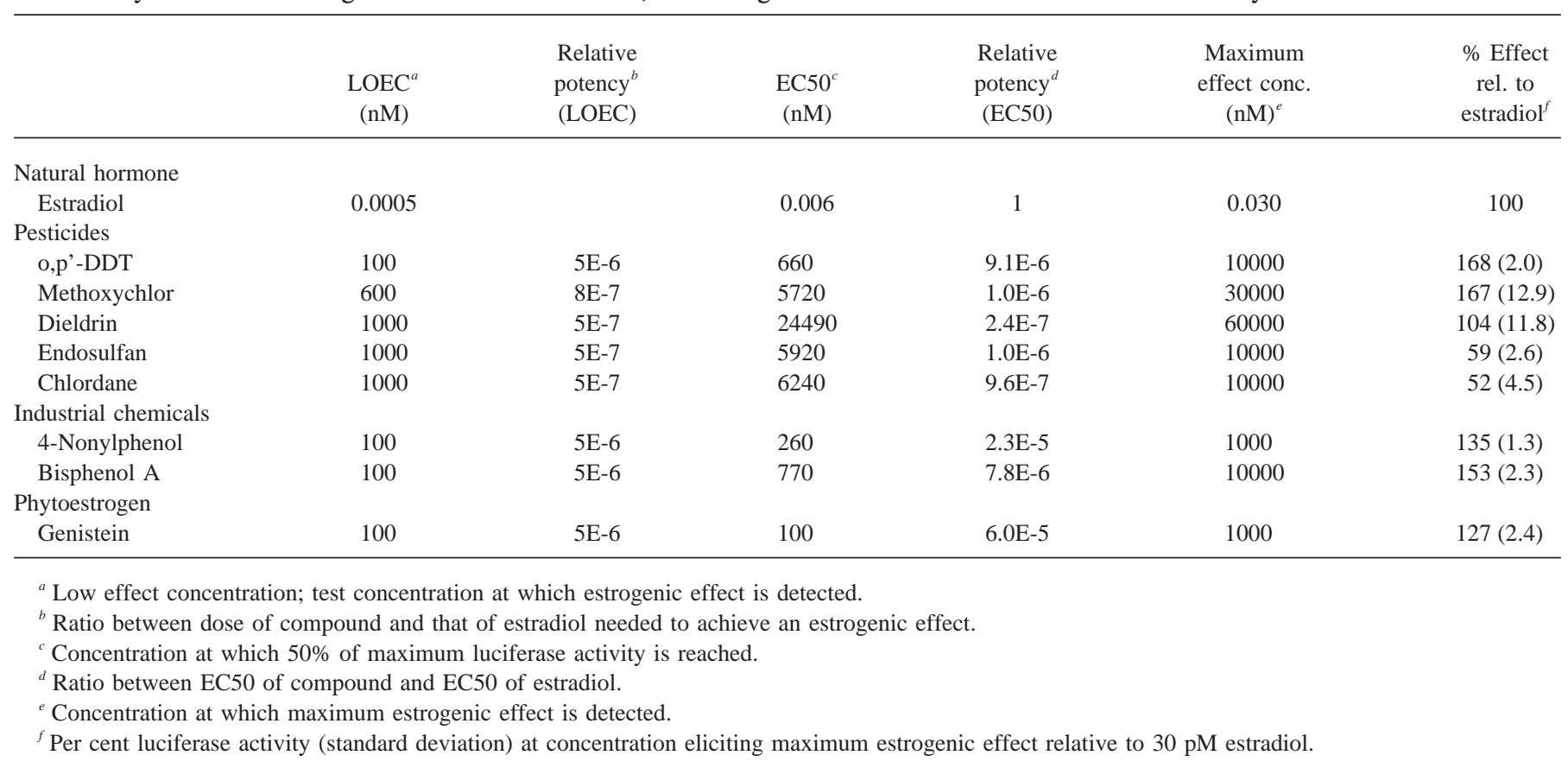

slightly estrogenic at 100 and $1000 \mathrm{nM}$ (about $10 \%$ activity relative to $6 \mathrm{pM}$ E2) (Fig. 4). Tamoxifen was far less anti-estrogenic when tested in combination with E2 than ICI 182, 780, as concentrations above $100 \mathrm{nM}$ were necessary to inhibit the E2-induced luciferase response by about $90 \%$.

Response to pseudo-estrogenic compounds. The specificity of the ER-CALUX assay was determined by testing the luciferase activity induced by a number of compounds previously shown in other in vitro assays to be estrogenic. These compounds were also estrogenic when tested in T47D.Luc cells (Table 1). Genistein, nonylphenol, and o,p'DDT were the most potent pseudo-estrogens tested (EC50 100, 260 and $660 \mathrm{nM}$, respectively) (Table 1). With the exception of dieldrin and methoxychlor, all compounds tested at concentrations above $30 \mu \mathrm{M}$ demonstrated cytotoxic effects (data not shown). The organochlorine pesticides tested induced luciferase in a dose-response related manner (Fig. 5). A number of compounds, including nonylphenol, genistein, o,p'DDT, methoxychlor, and bisphenol A showed maximum luciferase activity exceeding that of estradiol at $30 \mathrm{pM}$, though at concentrations 3000-300,000 times that of estradiol (Table 1).

Combination effects of pseudo-estrogens. Pseudo-estrogenic compounds were tested in combination with a low concentration of E2 ( $3 \mathrm{pM})$ in order to determine potential interactive effects when tested in mixtures (Fig. 6). All combinations tested showed additive luciferase activity, i.e., not significantly different from the arithmetic sum of the compounds tested individually. To determine interactive effects, the pseudo-estrogens endosulfan, dieldrin and chlordane were also tested together at concentrations eliciting luciferase activity within the lower linear range of the estradiol standard curve (between 1 and 6 pM E2 equivalents). The combination of endosulfan with dieldrin at concentrations between 3 and $6 \mu \mathrm{M}$ resulted in luciferase activity showing more than additive in-

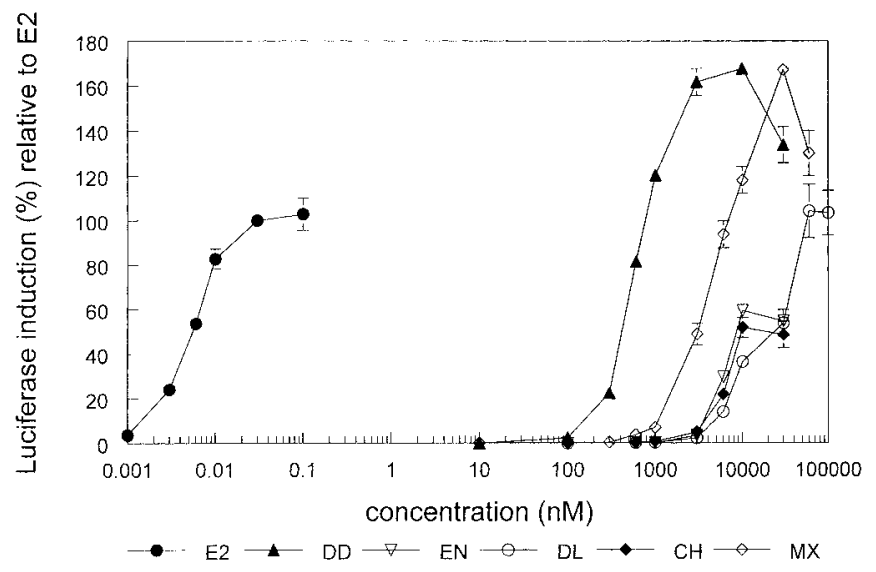

FIG. 5. Luciferase induction (\%) of pesticides relative to $30 \mathrm{pM}$ estradiol (E2) in the ER-CALUX assay. T47D.Luc cells were treated for $24 \mathrm{~h}$ with o,p'DDT (DD), chlordane (CH), endosulfan (EN), dieldrin (DL), and methoxychlor (MX) $(n=3$, avg \pm std). 


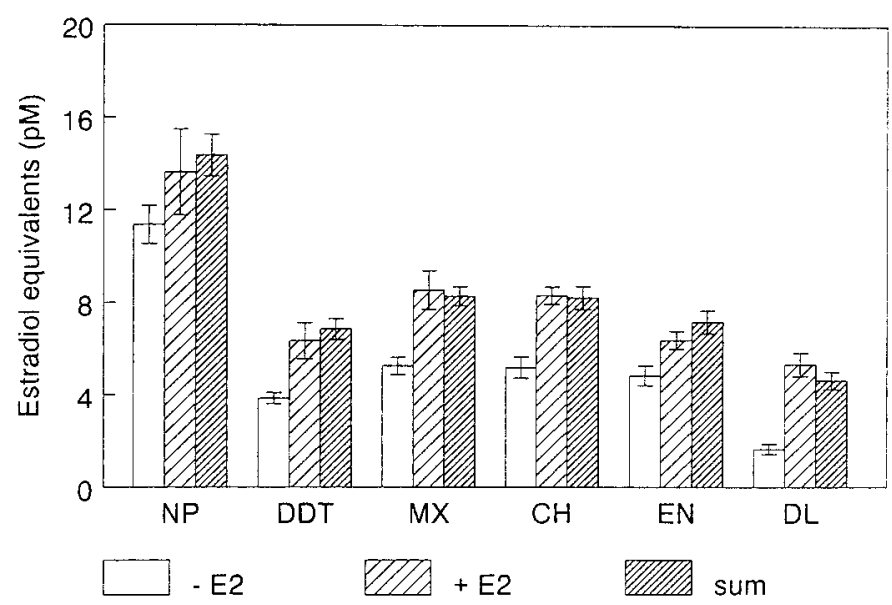

FIG. 6. Interactive estrogenic activity of environmental chemicals with estradiol (E2) in the ER-CALUX assay. T47D.Luc cells were exposed for $24 \mathrm{~h}$ to environmental chemicals with (striped bars) or without (open bars) coadministration of $3 \mathrm{pM}$ E2. Double-striped bars show the arithmetic sum of luciferase activity obtained by adding the induction by the individual compound with induction elicited by $3 \mathrm{pM} \mathrm{E2}$. o,p'DDT (DDT) and 4-nonylphenol (NP) were tested at a concentration of $200 \mathrm{nM}$. Methoxychlor (MX) was tested at a concentration of $2 \mu \mathrm{M}$. Chlordane $(\mathrm{CH})$, dieldrin(DL), and endosulfan (EN) were tested at a concentration of $4 \mu \mathrm{M}(n=6$, ave \pm std $)$.

teraction. The luciferase activity elicited by these combinations significantly exceeded the arithmethic sum of their individual luciferase activity, though by a factor of less than 2 (Fig. 7). At 7 and $8 \mu \mathrm{M}$, the interaction between endosulfan and dieldrin was additive or slightly less than additive (Figure 7). The combination of endosulfan and chlordane tested at concentrations between 3 and $5 \mu \mathrm{M}$ resulted in additive luciferase

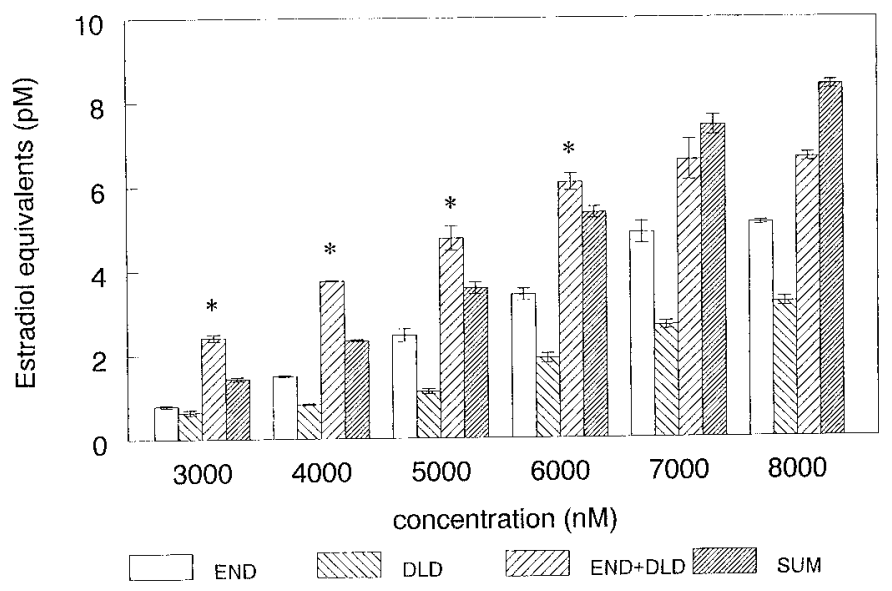

FIG. 7. Interactive effects of mixtures of the pseudo-estrogens endosulfan (END) and dieldrin (DLD) the ER-CALUX assay. T47D.Luc cells were treated with each pseudo-estrogen and with the two combined (END + DLD). Double-striped bars on the right show the arithmetic sum (SUM) of luciferase activity obtained by adding the induction elicited by the individual compounds ( $n=6$, avg \pm std, *significantly higher than arithmetic sum, $p<0.01$ ).

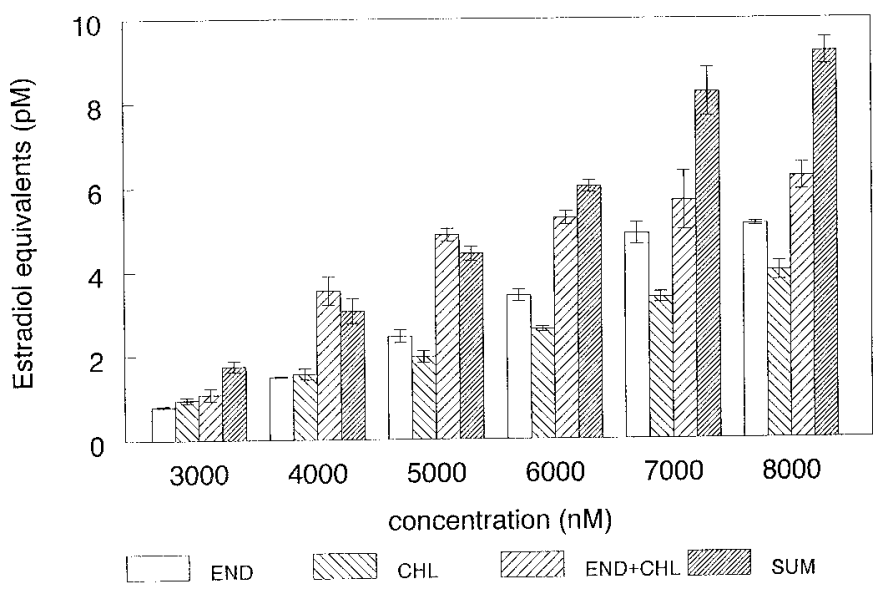

FIG. 8. Interactive effects of mixtures of the pseudo-estrogens endosulfan (END) and chlordane (CHL) in the ER-CALUX assay. T47D.Luc cells were treated with each pseudo-estrogen and with the two combined (END + CHL). Double-striped bars on the right show the arithmetic sum (SUM) of luciferase activity obtained by adding the induction elicited by the individual compounds ( $n=6$, avg \pm std, EC50 endosulfan: $\mathrm{nM}$; EC50 chlordane: $6240 \mathrm{nM})$.

activity (Fig. 8). When combined at concentrations higher than their individual EC50 values (6 to $8 \mu \mathrm{M}$ ), luciferase activity was less than additive (Fig. 8).

\section{DISCUSSION}

\section{Stable Transfection in ECC-1, MCF-7, and Hepa Cell Lines}

Attempts to stably transfect the pEREtata-Luc construct in ECC- 1 cells, as well as the chimeric Gal4-HEGO/17m5-G-Luc constructs in Hepa.1c1c7 and MCF-7 cells, resulted in constitutive, non-estradiol-inducible luciferase expression. JausonsLoffreda and co-workers also reported some hormone-independent luminescent clones after stable tranfection of chimeric Gal4 constructs in HeLa cells (Jausons-Loffreda et al., 1994). The reasons for the presence of these constitutive clones are not clear, but may be due to events during integration that resulted in a mutation in the promoter region of the luciferase gene, or to the influence of promoters around the integration site causing constitutive, E2-independent luciferase expression. Only one Hepa clone that was stably transfected with Gal4HEGO/17m5-G-Luc demonstrated estradiol-inducible luciferase activity, though this induction decreased in subsequent assays, indicating instability of the clone. Subculturing of this clone could result in clones with a more homogeneous population of luciferase-expressing cells.

\section{ER-CALUX Assay in Stably Transfected T47D Cell Line}

Stable transfection of the pEREtataLuc construct in T47D cells resulted in a sensitive, highly responsive cell line for the screening of compounds with anti-estrogenic activity. Estradiol concentrations as low as $0.5 \mathrm{pM}$ were detected, and an EC50 of 
TABLE 2

Potency Values for Maximum Effect Concentrations of Pseudo-Estrogens Relative to Estradiol According to in Vitro Assays for Estrogenicity

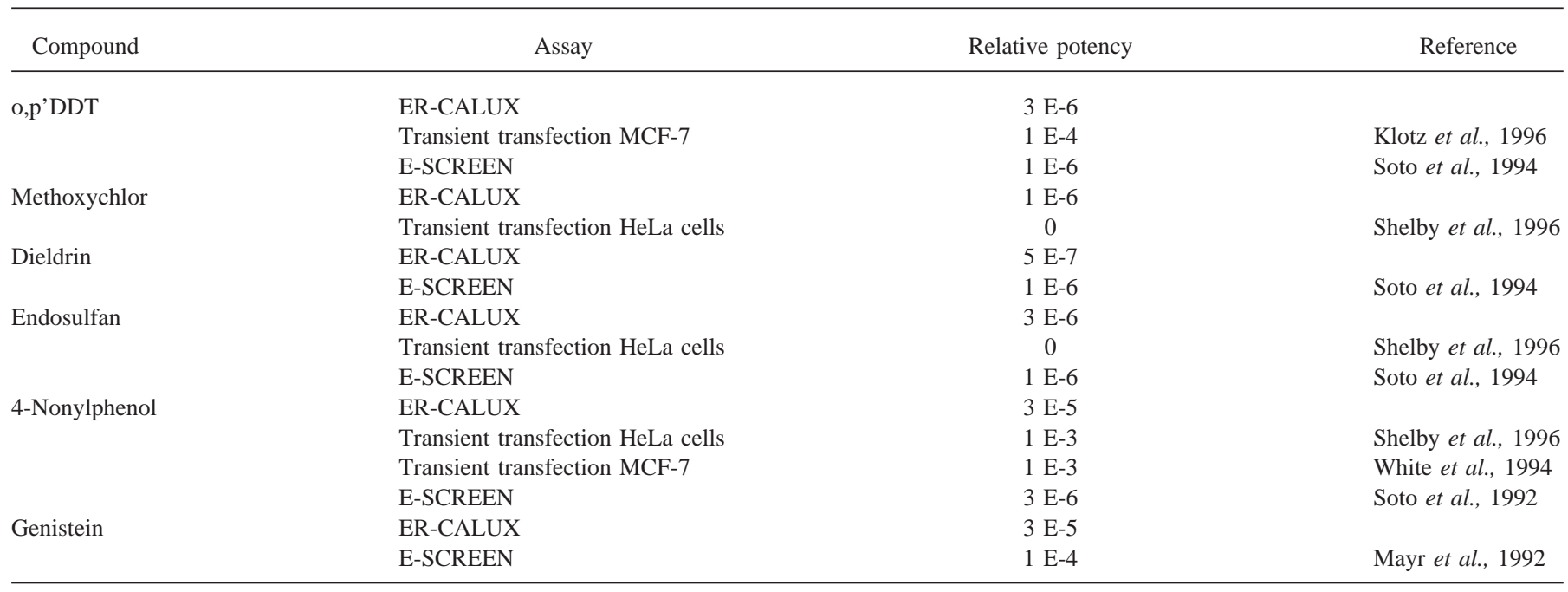

$6 \mathrm{pM}$ was found following a 24-h exposure to estradiol. The assay is also highly responsive, as luciferase induction in 24-well plates by 30 pM E2 was increased by about 100-fold relative to solvent controls. The assay appears also to be specific for estrogens, as other endogenous ligands tested, such as synthetic progestin and androgen, or retinoic acid, did not induce luciferase activity. Anti-estrogenicity of substances such as ICI 182,780 and tamoxifen could be demonstrated by measuring inhibition of luciferase induction with co-administration of estradiol. The prototypical Ah receptor agonist TCDD was also a potent anti-estrogen when measured in the ER-CALUX assay. These results are consistent with previous studies which demonstrate the anti-estrogenicity of TCDD in breast cancer cell lines, likely due to the complex cross talk between the AhR and ER signal transduction pathways (reviewed by Safe, 1995).

Response of pseudo-estrogens. A number of pseudo-estrogenic compounds were tested individually and in combination in order to determine their potency in the ER-CALUX assay. The phyto-estrogen genistein, nonylphenol, and the pesticide o,p'DDT were the most potent of the pseudo-estrogens tested. The environmental estrogens demonstrating induced luciferase activity in the ER-CALUX assays have also been previously shown to be estrogenic in both in vivo and in vitro assays: 4-nonylphenol (Jobling and Sumpter, 1993; Soto et al., 1991; White et al., 1994), o.p'DDT (Bitman, 1969, Fry and Toone, 1981, Klotz et al., 1996), methoxychlor (Gray et al., 1989, Schlenk et al., 1997), endosulfan (Arnold et al., 1996), dieldrin (Haake et al., 1987) and chlordane (Cranmer et al., 1984). Comparison of the potency values relative to estradiol shows that in general, lower potency values for environmental estrogens are calculated in the ER-CALUX than demonstrated with other ER-mediated reporter gene assays, such as transient transfections of ERE-reporter genes in HeLa and MCF-7 cells (Table 2). However, this factor of 10-100 fold difference in potency could be explained by the differences in estradiol concentrations required to produce a maximal response. For the ER-CALUX assay, maximum luciferase induction is reached at $30 \mathrm{pM}$ E2. For other assays, estradiol concentrations ranging from $1 \mathrm{nM}$ (Shelby et al., 1996) to $10 \mathrm{nM}$ (White et al., 1994) are used for calculation of relative potency. ER-CALUX relative potency values correlate well with those reported in MCF-7 cell proliferation assays, in which a maximum E2 effect concentration of $10-30 \mathrm{pM}$ is also found (Soto et al., 1992, 1994, 1995).

Interestingly, when tested at high concentrations $(>1000$ $\mathrm{nM}$ ), a number of compounds such as genistein, nonylphenol, bisphenol A, o,p'DDT, and methoxychlor elicited luciferase induction higher than that of the maximum induction by estradiol (Table 1). In a screening of estrogenic compounds using a recombinant yeast strain, Routledge and Sumpter also reported that exposure to both the genistein and the alkylphenol 4-tertoctylphenol resulted in higher reporter gene activity than by estradiol (Routledge and Sumpter, 1997). The mechanism of this super-agonism is not clear, but may be due to stimulated receptor and/or co-activation factor renewal by pseudo-estrogens or to effects on luciferase stability.

When tested in combination with 3 pM E2 in the ERCALUX assay, all test compounds showed additive luciferase activity (Fig. 6). However, when the pseudo-estrogens endosulfan, dieldrin, and chlordane were tested in combination in the ER-CALUX assay, the resulting interaction was not consistently additive. The combination of dieldrin with endosulfan resulted in luciferase activity slightly more than additive, 
TABLE 3

Comparison of Detection Limit (dl), EC50, and Responsiveness to Estradiol in Recombinant Receptor/Reporter Gene Assays with Stable or Transient Transfection of Estrogen-Receptor-Mediated Reporter Genes in Mammalian Cell Lines

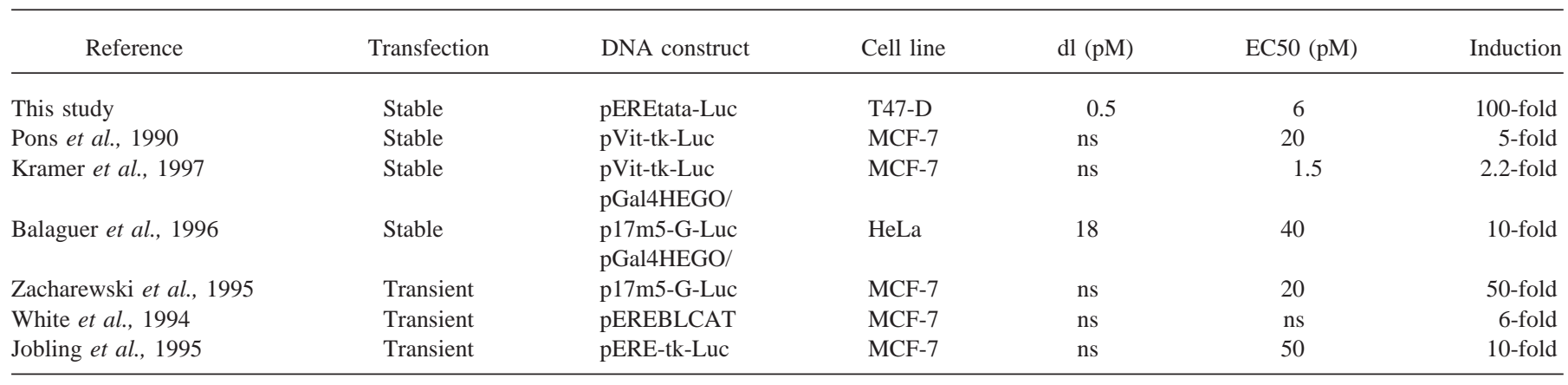

Note. ns, data not shown.

though significantly higher, than the arithmetic sum of the individual compounds (Fig. 7). The combination of endosulfan and chlordane was additive at the lower concentrations tested (3 to $6 \mu \mathrm{M}$ ). Gaido and coworkers have also reported the additive effects of endosulfan and chlordane when tested in combination in a yeast estrogen screen (Gaido et al., 1997). Less than additive luciferase induction by the combination of endosulfan and chlordane was observed at higher concentrations (7 and $8 \mu \mathrm{M}$ ) (Fig. 8). However, these concentrations were higher than the EC50 level of the individual compounds, so it is not surprising that the arithmetic sum of their individual activities was higher than activity elicited by the combination. These results indicate that weak environmental estrogens may act cumulatively and further research is warranted in the in vivo effects of mixtures of pseudo-estrogens.

Comparison of ER-CALUX with other in vitro assays. To our knowledge, in comparison to other recombinant receptor and/or reporter gene assays using stably or transiently transfected mammalian cells, the ER-CALUX assay is the most sensitive and responsive stably-transfected, estrogen-responsive cell line in existence (Table 3 ). The sensitivity and specificity of the ER-CALUX assay may be explained in part by the use of a minimal $E_{1} B$ promoter (TATA box only) in the pEREtata-Luc construct. Enhancer and promoter regions are absent in this minimal promoter. Other promoters used in response to element-regulated reporter genes generally consist of several hundred base pairs of 5' flanking regions, which may cause higher background activation levels (Cavailles et al., 1988, 1989). Also, the vigorous serum-stripping method used may contribute to the low background levels in the ERCALUX assay. The presence of serum-borne estrogens can result in high constitutive reporter gene activity and can be demonstrated by assessing the ability of anti-estrogens to reduce background levels (Bondy and Zacharewski, 1993). In the ER-CALUX assay, ICI 182,780 at concentrations up to 100 nM did not significantly antagonize background luciferase activity, demonstrating that serum-borne estrogens were very low. The ER-CALUX-assay procedure was also optimized to ensure the lowest possible background levels. Cells are plated 2 days prior to exposure with a medium renewal step on the second and third days. These medium renewal steps reduced background levels of serum-borne estrogens by a factor of 2 (data not shown).

The high responsiveness of the ER-CALUX assay may be due in part to the choice of the cell line. The T47D cell line appears to provide the cellular environment, such as high estrogen receptor levels and the availability of transcription factors, that are necessary for gene transcription. The presence of both $\mathrm{ER} \alpha$ and $\mathrm{ER} \beta$ subtypes in T47D cells has been confirmed using RT-PCR (Dotzlaw et al., 1996). Estrogen receptor levels in the cytosol of T47D cells have been reported to be $67.6 \pm 6.2 \mathrm{fmol} / \mathrm{mg}$ cytosol protein (Watanabe et al., 1990). The use of an enhanced luciferase reporter gene that was modified for optimal transcriptional activity in transfected eukaryotic cells (Sherf and Wood, 1994) may also have contributed to higher induction values. Comparison of EREtata constructs with enhanced vs normal luciferase in transient transfections in the 293 human embryonic kidney cell line showed a factor 5 increase in fold induction (data not shown).

The use of the ER-CALUX assay in stably transfected T47D.Luc cells offers many advantages in comparison to other in vitro bioassays, such as transient transfections of reporter gene constructs, yeast based assays, and cell proliferation assays, for assessing estrogenic substances. The ER-CALUX assay is rapid and simple, and detection in microtiter volumes is possible, allowing for qualitative and quantitative assessment of luciferase induction in a high throughput setup. Compared to transient transfections of estrogen-responsive reporter genes, the ER-CALUX assay is less cumbersome and time consuming, as it is not necessary to transfect DNA for each experiment. Problems with differences in quality of DNA and changes in luciferase activity due to cell culture conditions found with transient transfections (Zacharewski, 1997) are therefore avoided. A number of yeast-based assays have been 
developed to assess estrogenic substances that are very sensitive and responsive (Arnold et al., 1996; Routledge and Sumpter, 1997). Unlike the ER-CALUX assay, however, lack of antagonism of ER-mediated reporter gene expression by anti-estrogens has been demonstrated in yeast-based assays (Kohno et al., 1994; Lyttle et al., 1992). Permeability of compounds through yeast cell wall may also be a problem not encountered in the ER-CALUX assay (Legler, manuscript in preparation). In comparison to cell proliferation assays with estrogen-responsive cell lines like MCF-7, such as the ESCREEN (Soto et al., 1995), the ER-CALUX assay is more specific, rapid, sensitive, and responsive.

We believe that the ER-CALUX assay can form a valuable contribution to a careful selection of in vitro and in vivo assays used to identify and determine the anti-estrogenicity of compounds. The ER-CALUX assay is also currently being used to identify anti-estrogenic substances in complex environmental mixtures, such as sediment and water extracts (Legler, Ms. in prep.). Of course, the in vitro ERCALUX assay cannot completely reflect complex in vivo events such as the pharmacokinetics, metabolism, and accumulation of a compound. T47D.Luc cells possess some metabolic capabilities such as the cytochrome P450 enyzmes involved in the hydroxylation of estrogens and xenobiotics. For example, P450IA (data not shown, Kuil et al., 1998; Spink et al., 1998); P4501B (Spink et al., 1998) and $17 \beta$-hydroxysteroid dehydrogenase (Piao et al., 1997) activity has been reported in T47D cells. In an in vitro assay, cross-talk with other mechanisms not directly involving interaction with the ER signal transduction pathway may also be missed. In addition, caution should be exercised when using a breast cancer cell line expressing both ER $\alpha$ and $\operatorname{ER} \beta$ subtypes for the prediction of tissue-specific effects. Tissues such as prostate and ovary have been found to contain prominent ER $\beta$ expression (Kuiper et al., 1997). Differences in the binding affinities of compounds such as phytoestrogens, as well as in the transcriptional activity for both ER subtypes, have been demonstrated (Kuiper et al., 1998). Further research can determine whether estrogenic potency predicted in the ER-CALUX assay using human T47D.Luc cells may be extrapolated to other species such as fish, birds and reptiles. If not, recombinant reporter gene assays should be developed using species specific estrogen receptors in estrogen-sensitive cell lines from various species. To address many of these questions, biological validation is currently underway in fish to compare the reproductive effects of (mixtures of) estrogens in vivo to effects measured by the ER-CALUX assay.

\section{ACKNOWLEDGMENTS}

This study was supported by the Dutch Ministry of Transport, Public Works, and Water Management, National Institute for Coastal and Marine Management (RIKZ), project DG-286, as well as EC grant PL 95-1223. We thank A
Jeuken and I Sterenborg for their valuable contribution during development of the stable cell lines. J. Legler was supported by a Natural Sciences and Engineering Research Council of Canada PGS-B scholarship.

\section{REFERENCES}

Aarts, J. M. M. J. G., Denison, M. S., Cox, M. A., Schalk, A. C., Garrison, P. A., Tullis, K., de Haan, L. H. J., and Brouwer, A. (1995). Species-specific antagonism of Ah receptor action by 2,2',5,5'-tetrachloro- and 2,2'3,3',4,4' hexachlorobiphenyl. Eur. J. Pharmacol. Environ. Tox. 293, 463-474.

Arnold, S. F., Robinson, M. K., Notides, A. C., Guillette, L. J., Jr., and McClachlan, J. A. (1996). A yeast estrogen screen for examining the relative exposure of cells to natural and xenoestrogens. Environ. Health Perspect. 104, 544-548.

Balaguer, P., Joyeux, A., Denison, M. S., Vincent, R., Gillesby, B. E., and Zacharewski, T. (1996). Assessing the estrogenic and dioxin-like activities of chemicals and complex mixtures using in vitro recombinant receptorreporter gene assays. Can. J. Physiol. Pharmacol. 74, 216-222.

Berthois, Y., Katzenellenbogen, J. A., and Katzenellenbogen, B. S. (1986). Phenol red in tissue culture media is a weak estrogen: implications concerning the study of estrogen-responsive cells in culture. Proc. Natl. Acad. Sci. $U S A \mathbf{8 3}, 2496-2500$.

Bitman, J., Cecil, H. C., Harris, S. J., and Fries, G. F. (1969). Estrogenic activity of o,p'DDT in the mammalian uterus and avian oviduct. Science 162, 371-372.

Bondy, K. L., and Zacharewski, T. R. (1993). ICI 164,384-a control for investigating estrogen-responsive genes. Nuc. Acids Res. 21, 5277-5278.

Cavailles, V., Augereau, P, Garcia, M., and Rochefort, H. (1988). Estrogens and growth factors induce the messenger RNA of the $52 \mathrm{k}$-procathepsin-D secreted by breast cancer cells. Nucleic Acids Res. 16, 1903-1919.

Cavailles, V., Garcia, M., and Rochefort, H. (1989). Regulation of cathepsin-D and pS2 gene expression by growth factors in MCF7 human breast cancer cells. Mol. Endocrin. 3, 552-558.

Colborn, T., vom Saal, F. S., and Soto, A. M. (1993). Developmental effects of endocrine-disrupting chemicals in wildlife and human. Environ. Health. Perpect. 101, 378-384.

Cranmer, J., Cranmer, M., and Goad, P. (1984). Prenatal chlordane exposure: Effects on plasma corticosterone concentrations over the lifespan of mice. Environ. Res. 35, 204-210.

Dickson, R. B., and Lippman, M. E. 1995. Growth factors in breast cancer. Endocr. Rev. 16, 559-589.

Dotzlaw, H., Leygue, E., Watson, Peter, H., and Murphy, L. (1996). Expression of estroen receptor-beta in human breast tumors. J. of Clin. Endocrinol. Metab. 82, 2371-2374.

Evans, R. (1988). The steroid and thyroid hormone receptor superfamily. Science 240, 889-895.

Fry, D. M., and Toone, C. K. (1981). DDT-induced feminization of gull embryos. Science 231, 922-924.

Gaido, K. W., McDonnell, D. P., Korach, K. S., and Safe, S. H. (1997). Estrogenic activity of chemical mixtures: Is there synergism? CIIT Activities 17, 1-7.

Garrison, P. M., Tullis, K., Aarts, J. M. M. J. G., Brouwer, A., and Giesy, J. (1996). Species-specific recombinant cell lines as bioassay systems for the detection of 2,3,7,8-tetrachloro-dipenzo-p-dioxin-like chemicals. Fundam. Appl. Toxicol. 30, 194-203.

Gray, L. E, Ostby, J., Ferrell, J., Rehnberg, G., Linder, R., Cooper, R., Goldman, J., Slott, V. and Laskey, J. (1989). A dose-response analysis of methoxychlor-induced alterations of reproductive development and function in the rat. Fundam. Appl. Toxicol. 12, 92-108.

Green, S., Issemann, I., and Sheer, E. (1988). A versatile in vivo and in vitro 
eukaryotic expression vector for protein engineering. Nuc. Acids Res. 16, 369.

Haake, J., Kelley, M., Keys, B., and Safe, S. T. (1987). The effects of organochlorine pesticides as inducers of testosterone and benzo(a)pyrene hydroxylases. Gen. Pharmacol. 18, 165-169.

Hess, R. A., Bunick, D., Lee, K. H., Bahr, J., Taylor, J. A., Korach, K. S., and Lubahn, D. B. (1997). A role for oestrogens in the male reproductive system. Nature 390, 509-512.

Hoglund, M., Siden, T., and Rohme, D. (1992). Different pathways for chromosomal integration of transfected circular pSVneo plasmids in normal and established rodent cells. Gene 116, 215-222

Horwitz, K. B., and McGuire, W. L. (1978). Estrogen control of progesterone receptor in human breast cancer: Correlation with nuclear processing of estrogen receptor. J. Biol. Chem. 253, 2222-2228.

Ing, N. H., and O'Malley, B. W. (1995). The steroid hormone receptor superfamily: Molecular mechanisms of action. In Molecular Endocrinology: Basic Concepts and Clinical Correlations. (Weintraub, B. D., Ed.), pp. 195-215. Raven Press, New York.

Jausons-Loffreda, N., Balaguer, P., Roux, S., Fuentes, M., Pons, M., Nicolas, J. C., Gelmini, S., and Pazzagli, M. (1994). Chimeric receptors as a tool for luminescent measurement of biological activities of steroid hormones. $\mathrm{J}$. Biolumin. Chemilumin. 9, 217-221.

Jobling, S., Reynolds, T., White, R., Parker, M. G., and Sumpter, J. P. (1995). A variety of environmental persistent chemicals, including some phthalate plasticizers are weakly estrogenic. Environ. Health Perspect. 103, 582-587.

Jobling, S., and Sumpter, J. P. (1993). Detergent components in sewage effluent are weakly oestrogenic to fish: An in vitro study using rainbow trout (Oncorhynchus mykiss) hepatocytes. Aquat. Toxicol. 27, 361-372.

Klotz, D. M., Beckman, B. S., Hill, S. M., McLachlan, J. A., Walters, M. R., and Arnold, S.F. (1996). Identification of environmental chemicals with estrogenic activity using a combination of in vitro assays. Environ. Health Perspect. 104, 1084-1089.

Kohno, H., Gandini, O., Curtis, S. W., and Korach, K. S. (1994). Anti-estrogen activity in the yeast transcription system: Estrogen receptor mediated agonist response. Steroids 59, 572-578.

Korach, K. S., Metzler, M., and McLachlan, J.A. (1978). Estrogen activity in vivo and in vitro of some diethylstilbestrol metabolites and analogs. Proc. Natl. Acad. Sci. U S A 75, 468-471.

Kramer, V. J., Helferich, W. G., Bergman, A., Klasson-Wehler, E., and Giesy, J. P. (1997). Hydroxylated polychlorinated biphenyl metabolites are antiestrogenic in a stably transfected human breast adenocarcinoma (MCF-7) cell line. Tox. Aplp. Pharmacol. 144, 363-376.

Kuil, C. W., Brouwer, A., van der Saag, P. T., and van der Burg, B. (1998). Interference between progesterone and dioxin signal transduction pathways: Different mechanisms are involved in repression by the progesterone receptor A and B isoforms. J.. Biol. Chem. 273, 8829-8834.

Kuiper, G. J. M., Carlsson, B., Grandien, K., Enmark, E., Haggblad, J., Nilsson, S., and Gustaffson, J.A. (1997). Comparison of the ligand binding specificity and transcript tissue distribution of estrogen receptors $\alpha$ and $\beta$. Endocrinology 138, 863-870.

Kuiper, G. J. M., Enmark, E., Peto-Huikko, M., Nilsson, S., and Gustafsson, J. A. (1996). Cloning of a novel estrogen receptor expressed in rat prostate and ovary. Proc. Natl. Acad. Sci. U S A 93, 5925-5930.

Kuiper, G. J. M., Lemmen, J. G., Carlsson, B., Corton, J. C., Safe, S. H., Van der Saag, P. T., Van der Burg, B., and Gustafsson, J. A. (1998). Interaction of estrogenic chemicals and phytoestrogens with estrogen receptor $\beta$. Endocrinology 139, 4252-4263.

Lyttle, C. R., Damian-Matsumura, P., Juul, H., and Butt, T. R. (1992). Human estrogen receptor regulation in a yeast model system and studies on receptor agonists and antagonists. J. Steroid Biochem. Mol. Biol. 42, 677-685.

Mayr, U., Butsch, A., and Schneider, S. (1992). Validation of two in vitro test systems for estrogenic activities with zearalenone, phytoestrogens and cereal extracts. Toxicology $\mathbf{7 4 , 1 3 5 .}$

Migliaccio, S., Davis, V. L., Gibson, M. K., Gray, T. K., and Korach, K. S. (1992). Estrogens modulate the responsiveness of osteoblast-like cells stably transfected with estrogen receptor. Endocrinology 130,2617-2624.

Mosselman, S., Polman, J., and Dijkema, R. (1996). ER $\beta$ : Identification and characterization of a novel human estrogen receptor. FEBS Lett.. 392, $49-53$.

Murk, A. J., Legler, J., Denison, M. S., Giesy, J. P., Van de Guchte, C., and Brouwer, A. (1996). Chemical-activated luciferase gene expression (CALUX): A novel in vitro bioassay for Ah receptor active compounds in sediments and pore water. Fundam. Appl. Tox. 33, 149-160.

Piao, Y.-S., Pelttoketo, H., Jouppila, A., and Vihko, R. (1997). Retinoic acidsincrease $17 \beta$-hydroxysteroid dehydrogenase type 1 expression in JEG-3 and T47D cells, but the stimulation is potentiated by epidermal growth factor, 12-O-tetradecanoylphorbol-13-acetate and cychlic adenosine 3',5'-monophosphate only in JEG-3 cells. Endocrinology 138, 898-904.

Pons, M., Gagne, D., Nicolas, J. C., and Mehtali, M. (1990) A new cellular model of response to estrogens: A bioluminescent test to characterize (anti)estrogen molecules. Biotechniques 9, 450-459.

Routledge, E. J., and Sumpter, J. P. (1996). Estrogenic activity of surfactants and some of their degradation productes assessed using a recombinant yeast screen. Environ. Tox. Chem. 15, 241-248.

Safe, S. (1995). Modulation of gene expression and endocrine response pathways by 2,3,7,8-tetrachlorodibenzo-p-dioxin and related compounds. Pharmacol. Ther. 67, 247-281.

Sambrook, J., Fritsch, E. F., and Maniatis, T. (1989). Molecular Cloning: A Laboratory Manual. (Irwin, N., Ed.). Cold Spring Harbor Laboratory Press, Cold Spring Harbor, New York.

Schlenk, D., Stresser, D. M., McCants, J. C., Nimrod, A. C., and Benson, W. H. (1997). Influence of b-naphtoflavone and methoxychlor pretreatment on the biotransformation and estrogenic activity of methoxychlor in channel catfish (Ictalurus punctatus). Toxicol. Appl. Pharmacol. 145, 349-356.

Shelby, M. D., Newbold, R. R., Tully, D. B., Chae, K, and Davis, V. L. (1996) Assessing environmental chemicals for estrogenicity using a combination of in vitro and in vivo assays. Environ. Health. Perspect. 104,1296-1300.

Sherf, B. A., and Wood, K. V. (1994). Firefly luciferase engineerd for improved genetic reporting. Promega Notes 49,14-21.

Soto, A. M., Chung, K. L., and Sonnenschein, C. (1994) The pesticides endosulfan, toxaphene and dieldrin have estrogenic effects on human estrogen sensitive cells. Environ. Health Perspect. 102, 380-383.

Soto, A. M., Jusiticia, H., Wray, J. W., and Sonnenschein, C. (1991). P-Nonylphenol: An estrogenic xenobiotic released from "modified" polystyrene. Environ. Health Perspect. 92, 167-173.

Soto, A. M., Lin, T. M., Justicia, H., Silvia, R. M., and Sonnenschein, C. (1992) An "in culture" bioassay to assess the estrogenicity of xenobiotics. In Chemically Induced Alterations in Sexual Development: The Wildlife/Human Connection. (Colborn, T., and Clement, C., Eds.), pp. 295-309. Princeton Scientific, Princeton, NJ.

Soto, A. M., Sonnenschein, C., Chung, L. K., Fernandez, M. F., Olea, N., and Olea Serrano, F. (1995). The E-SCREEN assay as a tool to identify estrogens: An update on estrogenic environmental pollutants. Env. Health Persp. 103(suppl. 7), 113-122.

Spink, D. C., Spink, B. C., Cao, J. Q, Depasquale, J. A., Pentecost, B. T., Fasco, M. J., Li, Y., and Sutter, T. R. (1998). Differential expression of CYP1A1 and CYP1B1 in human breast epithelial cells and breast tumor cells. Carcinogenesis 19, 291-298.

te Riele, H., Maandag, E. R., Clarke, A., Hooper, M., and Berns, A. (1990). Consecutive inactivation of both alleles of the pim-1 proto-oncogene by homologous recombination in embryonic stem cells. Nature 348, 649-651. van der Burg, B., Rutteman, G. R., Blankestein, M. A., de Laat, S. W., and van 
Zoelen, E. J. J. (1988). Mitogenic stimulation of human breast cancer cells in a growth factor-defined medium: synergistic action of insulin and estrogen. J. Cell Physiol. 134, 101-108.

Watanabe, T. Junzheng, W., Morikawa, K., Fuchigami, M., Kuranami, M., Adachi, I, Yamaguchi, K., and Abe, K. (1990). In vitro sensitivity test of breast cancer cells to hormonal agents in a radionucleotide-incorporation assay. Jpn. J. Cancer Res. 81, 536-543.

White, R., Jobling, S., Hoare, S. A., Sumpter, J. P., and Parker, M. G. (1994).
Environmentally persitstent alkylphenolic compounds are estrogenic. Endocrinology 135, 175-182.

Zacharewski, T. R. (1997) In vitro bioassays for assessing estrogenic substances. Environ. Sci. Technol. 31, 613-623.

Zacharewski, T. R., Berhane, K., Gillesby, B. E., and Burnison, B. K. (1995). Detection of estrogen- and dioxin-like activity in pulp and paper mill black liquor and effluent using in vitro recombinant receptor/reporter gene assays. Environ. Sci. Technol. 29, 2140-2146. 